\title{
Kajian Sosio-Ekologis Mengenai Pusat Kerajaan Demak
}

\section{Eko Punto Hendro}

Keywords: environment, kingdom center, reconstruction, settlement

\section{How to Cite:}

Hendro, E. P. Kajian Sosio-Ekologis Mengenai Pusat Kerajaan Demak. Berkala Arkeologi, 15(3), 47-59. https://doi.org/10.30883/jba.v15i3.670

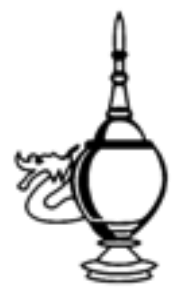

\section{Berkala Arkeologi}

https://berkalaarkeologi.kemdikbud.go.id/

Volume 15 No. 3, 1995, 47-59

DOI: $10.30883 /$ jba.v15i3.670

This work is licensed under a Creative Commons Attribution-NonCommercialShareAlike 4.0 International License. 


\title{
KAJIAN SOSIO-EKOLOGIS MENGENAI PUSAT KERAJAAN DEMAK
}

\author{
Eko Punto Hendro \\ (Fakultas Sastra UNDIP)
}

\section{Pendahuluan}

Sebagai kerajaan Islam pertama di Jawa nama Demak populer di kalangan masyarakat Jawa, khususnya Jawa tengah. Lebih-lebih Kasultananan Demak yang meninggalkan salah satu kejayaannya berupa Masjid Agung Demak. Masjid tersebut sampai saat ini masih dikunjungi para peziarah baik dari Jawa maupun luar Jawa.

Baik sumber-sumber tradisional maupun asing memberikan informasi, pendiri Kasultanan Demak adalak Raden Patah. la putra raja Kertabhumi raja Majapahit terakhir, dari hasil perkawinannya dengan seorang putri Cina. Hanya saja ibunya diserahkan kepada Arya Damar (Adipati Palembang) sewaktu Raden Patah masih berada dalam kandungan. Hasil perkawinan Arya Damar dengan puteri Cina melahirkan seorang putera yang bernama Raden Kusen. Dengan demikan antara Raden Patah dengan Raden Kusen satu ibu lain ayah (Graaf \& Pigeaud, 1985:198; Cortesao,1944:183; Babad Tanah Jawi,1941:47, Serat Kandha 1988:11).

Setelah dewasa Raden Patah dan Raden Kusen berangkat ke Jawa untuk mengabdi kepada raja Majapahit. Namun demikian sesampainya di Jawa Raden Patah mengurungkan niatnya mengabdi ke Majapahit karena ia lebih suka berguru agama Islam kepada Sunan Ampel di Surabaya. Sebaliknya Raden Kusen meneruskan perjalanannya ke Majapahit yang kelak diangkat menjadi Adipati Terung (Babad Tanah Jawi, 1941:51; Graaf, 1985:61; Serat Kandha,1988:12). Setelah cukup menguasai agama Islam, atas nasehat Sunan Ampel, Raden Patah disuruh membuka hutan Gagahwangi yang kemudian terkenal dengan nama Demak Bintoro, serta mendirikan masjid dan menjadi guru agama (Babad Tanah Jawi, 1941:52, Carub Kandha, 1980;665). Setelah De-mak menjadi kuat, Raden Patah bermaksud menyerang Majapahit yang belum Islam. Menurut serat Kandha serangan itu terjadi pada 1399 Ç dan dalam pertempuran itu Patih Gajah Mada dan raja Majapahit bersama keluarganya melari-kan diri ke Senggaluh. Setahun kemudian Seng-galuh dihancurkan oleh prajurit Demak. Jatuhnya Senggaluh merupakan keruntuhan Majapahit ditandai dengan Candrasengkala sirna ilang kertaning bhumi atau 1400 Ç (1478 M).

Sesudah jatuhnya Majapahit Raden Patah dengan dukungan para para Wali dinobatkan menjadi raja Islam di Kasultanan Demak. Sebagai raja Islam Raden Patah lebih menyandarkan kekuatan militer dan ekonominya pada kota-kota pelabuhan dagang di sepanjang pantai Jawa terutama dari Cirebon sampai Madura yang sudah di Islamkan. la kurang menyadari rakyat di pedalaman dengan pertanian sebagai basis ekonominya dapat dibina menjadi kekuatan ekonomi dan militer yang handal seperti pada jaman Majapa-hit. Oleh karena itulah negara. Demak yang Islam kurang populer di daerah-daerah pedalaman Jawa. Walaupun secara lambat laun Isiam menyebar ke daerah pedalaman, tetapi banyak bercampur dengan tradisi pra Islam.

Sebagai kerajaan yang menyandarkan perekonomiannya pada perdagangan, maka perhatian Demak lebih diutamakan untuk menguasai kota-kota pelabuhan dagang. Inilah salah satu sebab utama yang mendorong Demak menyerang Portugis di Malaka sebagai saingan utama Demak dalam perdagangan rempah-rempah. Serangan itu dilakukan oleh Adipati Unus (penggan-ti Raden Patah) pada tahun 1512 dan 1513 , akan tetapi kedua serangan itu selalu mengalami kegagalan (Cortesao, 1944:184; De Graaf,1985:49-50)

Pada masa pemerintahan Sultan Trenggana (1521-1546), pengganti Adipati Unus yang meninggal secara mendadak setelah serangannya kedua ke Malaka tahun 1521, juga pernah dikirim ekspedisi militer ke Sunda Kelapa di bawah pimpinan Sunan Gunung Jati untuk menundukkan raja Sunda Kelapa yang bersekutu dengan Portugis. Hal itu terjadi pada tahun 1526 dan Sunda Kelapa berhasil dikuasai. Disamping itu Sunan Gunung Jati berhasil mengusir orang-orang Portugis yang datang ke Sunda Kelapa untuk mendirikan benteng (Graaf \& Pigeaud,1985:147). Pada tahun 1546 Sultan Trenggana memimpin sendiri ekspedisi militer untuk menundukkan Panarukan yang tidak mau mengakui kekuasaan Demak. Namun dalam ekspedisi itu Sultan Trenggana diberitakan meninggal secara mendadak (Graaf \& Pigeaud, 1985:72-73; Tjandrasasmita, 1984:36)

Sepeninggal Sultan Trenggana Kasultanan Demak tidak berlanjut lagi, namun belum diketahui dengan pasti runtuhnya kerajaan Demak ini disebabkan oleh serangan musuh dari Panarukan atau akibat dari adanya perebutan kekuasaan dari kalangan kerabat. Setelah Sultan Trenggana meninggal kemudian muncul Arya Penangsang yang membunuh beberapa keturunan Sultan Demak terakhir ini. Namun ia dibunuh oleh Jaka Tingkir, dan atas kemenangan ini Jaka Tingkir memindahkan kerajaan Demak Ke Pajang. 
Walaupun ada tiga Sultan yang pernah memerintah Kasultanan Demak yang pengaruhnya sampai ke luar Jawa, namun sampai kini kondisi pusat kerajaan belum diketahui dengan pasti. Diperkirakan lokasi kraton atau pusat kerajaan ini berada di pusat kota Demak sekarang, karena di kota ini dijumpai Masjid Agung Demak, merupakan peninggalan kerajaan yang terletak di pusat kerajaan. Sedikitnya data/peninggalan arkeologi berkenaan dengan kerajaan ini menyebabkan tidak diketahuinya kondisi pusat kerajaan. Namun adanya beberapa toponim yang masih tersisa serta kondisi lingkungan geografis, kiranya merupakan data-data yang dapat digunakan untuk mencoba mengkaji secara sosioekologis mengenai pusat kerajaan Demak, tentunya dengan melihat proses-proses perubahannya

\section{Kondisi Lingkungan Geografis Dan Perubah- annya}

Munculnya suatu kota pusat kerajaan tidak lepas dari kondisi lingkungan geografis yang melatarinya. Dalam hal ini raja atau para penguasa kota tentu akan memilih suatu tempat (lokasi) sebagai pusat pemerintahan pada daerah-daerah yang baik, strategis dan memenuhi syarat geografis, agar mudah dan menguntungkan untuk mengkoordinasikan masalah-masalah politik, ekonomi dan budaya. Demikian pula bagi Sultan atau penguasa kerajaan Demak, dalam memilih lokasi pusat kerajaan mempertimbangkan faktor geografis (geopolitik). Adanya sungai Tuntang (lama) yang melintas pusat kota diperkirakan merupakan salah satu pertimbangan untuk menentukan lokasi pusat kerajaan, karena dilihat dari bekas-bekasnya diperkirakan sungai ini pada jaman dahulu cukup lebar (sekitar $50 \mathrm{~m}$ ) dan dapat dilayari sampai ke daerah pedalaman. ${ }^{1}$ Lebih dari itu diperkirakan kota Demak pada jaman dahulu tidak jauh dari pantai seperti sekarang. De Graaf melukiskan bahwa letak kerajaan Demak sangat menguntungkan, baik untuk perdagangan maupun pertanian. Pada jaman dahulu distrik Demak terletak di pantai selat yang memisahkan pegunungan Muria dari Jawa. Selat ini diperkirakan agak lebar dan dapat dilayari dengan baik, sehingga kapal-kapal dagang dari Semarang dapat mengambil jalan pintas untuk berlayar ke Rembang. Tetapi sejak abad 17 selat ini sukar dilayari lagi sebagai akibat adanya proses pendang-

1 Kini telah dibuat kanal pada sungai Tuntang tersebut yang dialirkan di sebelah barat kota Demak, untuk menanggulangi banjir di kota Demak, dan sungai Tuntang yang asli (lama) kini tinggal berbentuk kecil, namun bekas-bekasnya masih terlihat bahwa sungai tersebut sebelumnya cukup lebar. kalan. ${ }^{2}$ Sejarah juga telah mencatat pada abad ke-16 Demak menjadi tempat penimbunan perdagangan beras, yang berasal dari daerah-daerah pertanian di sebelah-menyebelah selat tersebut (Graaf \& Pigeaud, 1985:37).

Menurut Niermeyer (Bemmelen,1949) hingga abad 17 selat Semarang-Rembang dapat dilayari dari Demak lewat Kudus dan Pati menuju Rembang. Sekitar abad 16-17 Jepara yang berada di kaki barat Gunung Muria merupakan pelabuhan penting, dan dari sini dapat berhubungan langsung melalui air (kapal) dengan daerah-daerah selatannya seperti Demak, Kudus dan Pati. Pada sekitar abad ini daerah-daerah di kaki barat dan selatan Gunung Muria, seperti Jepara, Kalinyamat, Welahan, Mijen, Kudus dan Pati merupakan daerah yang berada di tepi pantai pulau Muria di utara selat, sedangkan Demak terletak di tepi pantai pulau Jawa di selatan selat. De Graaf \& Pigeaud (1985) juga menyebut setelah jatuhnya Juwana, kerajaan Demak menjadi penguasa mutlak selat ini.

Pada saat sekarang selat tersebut menjadi daratan, akibat adanya proses pembentukan tombolo atau proses sedimentasi. Menurut penelitian Ongkosongo(1981) tombolo yang muncul di daerah bekas selat Muria-Jawa merupakan yang terbesar di Pulau Jawa, $\pm 14 \mathrm{~km}$.

Tombolo merupakan suatu daerah yang menghubungkan antara suatu pulau dengan daratan utama, dan selat ini mungkin telah menjadi tombolo terbesar di pulau Jawa (Ongkosongo. 1981). Beberapa faktor yang menyebabkan selat ini semakin menjadi dangkal dan akhirnya menjadi daratan, antara lain awal selat ini dangkal. tidak begitu lebar (lebar selat lebih kecil dari daratan pulau yang ada), dan proses sedimentasi berjalan intensif. Beberapa sungai yang membawa material ke arah Depresi Semarang-Rembang datang dari beberapa kawasan antara lain Zona Rembang (timur), Zona Kendeng (selatan). kompleks Gunung Muria (utara) dan sebagian dari Paparan Laut Jawa. Proses sedimentasi relatif intensif dari waktu ke waktu hingga sekarang daerah ini menjadi dataran (rendah).

Dengan adanya selat yang pernah ada di antara kawasan pegunungarı Muria dan Pulau Jawa, maka pusat kerajaan Demak diperkirakan terletak di kawasan pantai dan tidak jaun dari se-

2 Menurut De Graaf pada abad ke-17 selama musim hujan orang dapat berlayar dengan sampan lewat tanah yang tergenang air, mulai dari Jepara sampai Pati di tepi sungai Juwana. Pada tahun 1657 Tumenggung Pati mengumumkan bahwa ia bermaksud menggali saluran air dari Demak ke Juwana. Boieh jadi ia menginginkan memulihkan jalan air lama 
lat tersebut. Di samping itu pusat kerajaan ini terletak di tepi sungai Tuntang (lama). Nampaknya sungai ini cukup lebar ( $\pm 50 \mathrm{~m}$ ) dan dapat dilayari sampai ke daerah pedalaman di sebelah selatan daerah Demak (Graaf \& Pigeaud, 1985). ${ }^{3}$ Dengan adanya sungai yang melintas ini, maka kawasan dataran rendah Demak ini menjadi daerah yang cukup subur. Namun demikian sungai ini cukup potensial pengaruhnya terhadap pembentukan daratan (tombolo) di kawasan selat, di samping sungai-sungai lainnya yang mengalir dari kompleks Gunung Muria, Zona Rembang dan Zona Kendeng (lihat lampiran Peta Topografi WedungWelahan yang telah dimodifikasi).

Posisi pusat kerajaan Demak terletak di tepi sebuah sungai dan tidak jauh dari pantai, hal ini ditegaskan oleh Tome Pires yang pernah mengunjungi pusat kerajaan Demak, Demak (sebagai pelabuhan pusat perdagangan) terdapat sungai yang penting, kapal-kapal dari luar tidak dapat masuk melayarinya kecuali bila air laut sedang pasang (Cortesao,1944:185). Sebagai daerah pelabuhan penting Demak merupakan suatu kota pusat kerajaan yang memiliki sebuah istana raja atau kraton. Menurut Tome Pires daerah ini lebih luas daripada Cirebon, Tegal, Semarang dan Jepara, dan jumlah penduduknya jauh lebih banyak jika dibandingkan dengan daerah-daerah tersebut (Cortesao, 1944:xxv-xxvi).

Penelitian yang pernah dilakukan oleh Pus-lit Arkenas pada sekitar tahun 1975-76 menemukan situs pemukiman di desa Tridonorejo Kec. Bonang Kab. Demak, yaitu suatu desa yang terletak di dekat pantai Moro Demak. Namun kemungkinan situs ini muncul di masa akhir atau setelah runtuhnya kerajaan Demak, atau masamasa setelah terjadinya proses sedimentasi di kawasan pantai Demak. Tampaknya belum dilakukan analisis secara mendalam terhadap hasil temuan itu, sehingga belum dapat disimpulkan secara ilmiah seperti diutarakan dalam kesimpulan penelitian (Ambary dkk, 1977).

\section{Kondisi Sosial Budaya Pusat Kerajaan Demak}

Sampai kini secara tepat belum diketahui lokasi bekas kraton Demak, sebab reruntuhan bangunan kraton sudah hilang dan tidak ber-

${ }^{3}$ Sejak jaman kolonial aliran sungai Tuntang ini telah dialihkan dalam suatu kanal di sebelah barat kota Demak. Hal ini mungkin dilakukan untuk menanggulangi bahaya banjir di kota Demak. Karena itu sunga: Tuntang yang masih tersisa di pusat kota Demak disebut Sungai Tuntang Lama, walaupun kini hanya berebntuk sungai kecil, tetapi bekas-bekas yang menunjukkan sungai tersebut cukup lebar masih tertihat. bekas. Menurut sumber Belanda jalan kereta api yang dibangun pemerintah kolonial sekitar akhir abad-19 tepat melalui pusat kerajaan ini. Keadaan ini juga diperjelas dengan J.F.G. Brumund yang pada pertengahan abad ke-19 pernah mengunjungi Demak. la mengatakan bahwa hanya sedikit yang dapat diceriterakan mengenai peninggalan-peninggalan kerajaan Islam Demak. Pada waktu itu kota ini terdapat sebuah mesjid yang sudah berdiri sejak Sultan Demak pertama dan telah diperbaiki tahun 1848. Menurut keterangan penduduk setempat serambi mesjid ini dibawa dari kraton Majapahit. Di halaman mesjid terdapat makam para Sultar Demak yaitu Raden Patah, Sabranglor, dan Trenggono. Di depan mesjid terdapat alun-alun, dan di sisi alun-alun terdapat sebidang tanah datar memanjang yang oleh penduduk dinamakan setinggil sebagai tempat kraton Sultan Demak. Di atas tanah setinggil tersebut, pada saat itu berdiri sebuah gudang garam (Encyclopadie van Nederlandsch-Indiè Ji.I: 433; Brumund, 1860:162).

Di samping laporan perjalanan orang asing beberapa sumber tradisional Babad juga memberikan indikasi mengenai kraton Demak. Walaupun harus dengan hati-hati dalam menggunakannya, beberapa sumber babad menceriterakan di pusat kerajaan ini dibangun sebuah mesjid oleh para wali, dan letak kratonnya tampak tidak jauh dari lokasi mesjid. Ini dapat diketahui dari peristiwa sesudah runtuhnya kerajaan Majapahit yang dikisahkan oleh Serat Babad Tembayat jilid 3.

Selesai persiapan semuanya, bangsal pengrawit dan pangapit Majapahit diusung ke Bintara.

Bangsal pengapit dipergunakan untuk serambi mesjıc Demak.

Bangsal pangrawit diletakkan di pagelaran Bintara. Tak ubahnya bagaikan pagelaran Majapahit saja.

Demikian pula, Adipati Natapraja memerintahkan un-tuk membawa masuk semua harta kekayaan Maja-pahit Hendaknya digelar di alun-alun. semua upacara kebesaran Prabu Brawi-jaya Majapahit.

Tampak dari kejauhan pagelaran Bintara bercahaya dan agung.

Konon sang Adipati Natapraja pergi ke mesjid Demak untuk menemui para waliyollah yang sedang mengerjakan pemasangan serambi mes-jid (Serat Babad Tembayat, 1985: 39-42).

Dari ceritera itu diperoleh gambaran pusat kota Demak terdapat tiga unsur bangunan yang penting yaitu kraton, alun-alun dan mesjid yang jarak satu dengan lainnya tidak jauh. Hal yang sama juga diceritakan dalam Babad Jaka Tingkir. Satu hal yang cukup menarik dari babad ini adalah indikasi arah hadap kraton Demak.

Keesokan harinya diadakan upacara garebegan. Sultan Demak berkenan mengadakan paseban agung di sitinggil Demak. Sultan duduk di singgasana manikwungu menghadap ke utara, kiri kanan Sultan duduk 
para walitwali pangarsa. Wali pawingking berada di mesjid bersama dengan para pandita. Para ulama, kukuma, abid, sulaka, pukaha berada di serambi mesjid dan halaman (Babad Jaka Tingkir, 1981:78).

Menurut Babad Majapahit dan Para Wali Jilid 3, di alun-alun kerajaan Demak setiap pagi diadakan seleksi para calon yang dapat diterima sebagai prajurit. Babad itu juga menunjukkan di depan kraton Demak terdapat "waringin kembar", seperti yang ada di kraton-kraton yang masih dapat dilihat dewasa ini (kraton Surakarta dan Yogyakarta). Selain itu Babad tersebut menceriterakan penyerbuan Kyai Ageng Sela ke Demak. Ketika sampai di "waringin kembar", kudanya dipanah oleh Sultan Demak hingga meninggal (Babad Majapahit \& Para Wali 3,1989:19-20, 60-61).

Kemungkinan tata kota kerajaan Demak, dijadikan model untuk membangun kota-kota kerajaan setelahnya. Babad Tanah Jawi menceriterakan Amangkurat il memerintahkan untuk membangun masjid di Kartasura dengan mencontoh model Masjid Demak (Meinsma, 1941:249).

Dari beberapa babad yang telah dikemukakan tadi dapatlah diketahui bahwa kraton, alunalun, dan mesjid merupakan unsur-unsur bangunan yang saling berdekatan di pusat kerajaan Demak. Jika tadi diceriterakan bahwa Sultan duduk di singgasana menghadap ke Utara, maka tentunya kraton itupun menghadap ke arah yang sa. ma. Dan, tidak tertutup kemungkinan kraton tersebut berlokasi di sisi Selatan alun-alun. Hal itu dapat dicocokkan lagi dengan letak kampung setinggil yang berada di bagian Selatan alun-alun kota Demak dewasa ini. Sayang, kraton tersebut kini sudah tidak berbekas.

Satu-satunya peninggalan kerajaan Demak yang berupa bangunan hanyalah Masjid Agung Demak yang kini masih berdiri di pusat kota Demak. Dengan adanya masjid ini maka diperkirakan bekas kraton Demak terletak di pusat kota Demak. Untuk menguji kebenaran perkiraan tentang pusat kerajaan Demak ini maka harus didasari dengan studi-studi baik yang besifat tekstual, kontekstual, prosesual dan komparatif terhadap masjid tersebut berserta lingkungannya yang meliputi beberapa bagian dari kota Demak.

Dari sumber-sumber tradisional berupa cerita legenda dan kitab babad diketahui bahwa Masjid Agung Demak ini sangat berperan dalam sejarah masuknya agama Islam di pulau Jawa. Konon masjid didirikan oleh Wali Songo serta digunakan oleh para ulama tersebut sebagai tempat pertemuan dalam membicarakan soal-soal keagamaan dan masalah Islam lainnya. Cerita legenda yang bersifat simbolik mengisahkan bahwa masjid tersebut dibangun Wali Songo dalam satu malam. Masjid ini memiliki empat saka guru besar, masing-masing sumbangan dari empat wali yaitu Sunan Kalijaga, Sunan Bonang, Sunan Kudus dan Sunan Gunungjati. Saka guru sumbangan Sunan Kalijaga disebutkan dibuat dari potongan-potongan kayu yang diikat dengan tali, yang disebut saka tatal. Dalam legenda ini Sunan Kalijaga menduduki tempat penting, beliaulah yang berjasa membetulkan kiblat masjid mengarah ke Mekkah, dan beliaulah yang memperolen baju wasiat "Antakusuma" yang jatuh dari langit di masjid itu ketika para wali sedang bermusyawarah. Baju itu juga disebut Kyai Gundil, dalam cerita tradisional dianggap sebagai salah satu pusaka raja-raja Jawa. Di samping itu ada legenda lain mengenai masjid Agung tersebut, misalnya dalam kaitannya dengan cerita Ki Ageng Sela dan sebagainya (Graaf \& Pigeaud,1974:32).

Mengenai tahun berdirinya Masjid Agung Demak sampai kini belum diketahui dengan pasti. karena tidak ditemukan angka tahun secara jelas menunjukkan berdirinya masjid tersebut Umumnya para ahli menafsirkan angka tahun berdirinya masjid tersebut berdasarkan sengkalan memet, prasasti atau petunjuk-petunjuk lain yang terdapat pada bangunan masjid tersebut dan kitab-kitab babad. Angka tahun tertua dalam menafsirkan berdirinya masjid ini dihubungkan dengan hiasan pintu depan masjid yang dikenal dengan sebutan lawang bledheg (pintu petir) dan ditafsirkan sebagai sengkalan memet yang berbunyi naga mulat salira wani, yang berarti tahun 1388 Ç atau tahun 1466 M (Sejarah dan Hari Jadi Kab.Demak,1991:19). Namun demikian umumnya para ahli menafsirkan bahwa berdirinya Masjid Agung Demak ini dihubungkan dengan hiasan kura-kura yang terdapat di atas ruang pengimaman (mihrab) masjid. Hiasan yang memperlihatkan kepala, badan, empat kaki dan ekomya ini sering ditafsirkan sebagai sengkalan yang menunjukkan angka tahun $1401 \mathrm{C}$ atau tahun $1475 \mathrm{M}$. Penafșıran ini mungkin memang dihubungkan dengan masa pemerintahan Raden Patah sebagaı Sultan Demak yang pertama (Anom, 1985-86:16; Graaf \& Pigeaud, 1985:35).

Diperkirakan di dalam proses pembangunan Masjid Agung Demak tersebut dilakukan penyempurnaan beberapa kali. Tahun 1429 Ç atau tahun 1506/1501507 M dapat dianggap sebaga tahun-tahun terakhir penyempurnaan pendirian masjid ini, karena menurut Serat Kandha pada tahun ini, seorang raja Demak pada tahun ketiga pemerintahannya berkenan menghadiri peresmian Masjid Raya di Demak. Menurut Graaf besar kemungkinan raja itu adalah Sultan Trenggana yang dikisahkan dalam kitab tersebut teian memegang pemerintahan di Demak sejak tahun 1504 M (Graaf \& Pigeaud,1985:35). Pada tahun-tahun 
ini Masjid Agung Demak disebut sebagai masjid raya yang artinya merupakan sebuah masjid jami atau masjid kerajaan. Beberapa fenomena yang menunjukkan bahwa masjid tersebut merupakan masjid jami atau masjid agung kerajaan adalah besarnya ukuran masjid tersebut, adanya maksurah, ${ }^{4}$ alun-alun di depan masjid. Selain itu masjid ini dicontoh dalam arsitektur dan lokasi penempatannya oleh beberapa kraton di Jawa sesudah kerajaan Demak, seperti di an-taranya kraton Banten, kraton Kasepuhan (Cirebon), kraton Kartasura, kraton Surakarta dan kra-ton Yogyakarta. Di samping itu masjid ini pernah beberapa kali mengalami perbaikan atau pemu-garan, antara lain dilakukan atas perintah Susu-hunan Paku Buwono I (1634), pada masa kolo-nial Belanda (1848 \& 1924) dan pada masa pe-merintahan RI (1966-1969 \& 1973-1985) (Anom, 1985-86).

Adanya masjid agung dan alun-alun yang ditemukan di kota Demak, dapat dibayangkan pada jaman dahulu sudah ada kraton. Konsepsi tentang alun-alun, masjid dan kraton ini dapat ditemukan di mana-mana, karena paling tidak di Jawa konsep ini sebagai sebuah tradisi simbolik pada suatu pemerintahan tradisional, yang melukiskan suatu kesatuan antara penguasa (raja), agama dan rakyat. Sejak jaman pra-Islam (jaman Hindu), misalnya kraton Majapahit juga dilengka-pi dengan alun-alun (wanguntur) dan bangunan suci (Siwa-Budha) yang terletak dalam satu kesatuan di pusat kota (kerajaan). Demikian pada masa-masa kemudian (jaman Islam) tradisi ini masih diteruskan dan dapat dilihat pada kraton ataupun reruntuhan kraton bahkan juga pusat kabupaten (kadipaten) yang ditemukan di Jawa. Dari kondisi seperti ini maka dapat dilukiskan bahwa masjid agung dan alun-alun di pusat kota Demak pada jaman dahulu juga berada dalam satu kesatuan dengan kraton Demak. Hal ini sesuai dengan pendapat Gideon Sjoberg (1960) bahwa masyarakat kota-kota tradisional (kota pra-industri) senantiasa masih memegang teguh kehidupan religius sebagai tempat berlindung. Karena itu para penguasa senantiasa akan dekat hubungannya dengan para ulama, dan kraton atau rumah penguasa senantiasa akan dekat dengan masjid atau bangunan suci.

4 Maksurah adalah sebuah tempat raja atau penguasa melakukan sho- lat, biasanya merupakan sebuah bilik kecil terlindung yang dibuat kayu dan di tempatkan di dekat (belakang) mihrab (ruang pengimaman). Mungkin juga maksurah Masjid Agung Demak ini dibangun pada masa-masa yang lebih kemudian oleh seorang Bupati Demak pada jaman kolonial.
Di samping itu umumnya secara tradisio-nal kraton atau rumah penguasa di Jawa itu menghadap ke arah utara atau paling tidak ke arah laut. Demikian pula kraton Kasepuhan (Cirebon) dan reruntuhan kraton Surasowan (Banten) yang sejaman dengan kraton Demak itu juga dilengkapi dengan masjid, alun-alun dan menghadap ke utara. Dengan melihat adanya tradisi seperti ini, tentu kraton Demak juga menghadap ke arah utara. Sebab selain bersan-dar pada konsep tradisional ini, secara ekologis posisi sungai Tuntang (lama) yang melengkung di sebelah utara alun-alun Demak itu merupakan kondisi yang strategis dan telah menyebabkan kawasan ini dipilih untuk lokasi kraton yang menghadap ke arah utara (lihat lampiran Peta Kota Demak) Di samping itu adanya (bekas) selat yang memisahkan kompleks gunung Muria dengan pulau Jawa (hingga abad 17) di sebelah utara kawasan Demak, hal ini secara tradisional juga mengharuskan kraton Demak menghadap ke utara. ke arah laut lepas (lihat lampiran peta topografi WedungWelahan yang telah dimodifikasi)

Di samping Masjid Agung Demak dan aiunalun, di kota Demak kini masih ditemukan beberapa toponim (nama tempat/ kampung) yang diperkirakan berkaitan dengan kondisi poia pemukiman penduduk kota kerajaan Demak di masa lampau. Beberapa toponim ini sekarang juga digunakan untuk memberi nama kampung, jalan atau gang-gang di kota Demak, walaupun mungkin juga telah mengalami pergeseran (penyempitan, perluasan atau pemindahan) dari lokasi semula. Di samping itu juga ditemukan toponım yang sudah tidak digunakan lagi tetapi masin dikenal oleh beberapa penduduk. Dari toponimto-ponim yang ditemukan di kota Demak ini dapat diklasifikasikan ke dalam 4 kelompok:

1. Toponim yang berkaitan dengan nama bangunan, yaitu setinggil, bale kambang, bentengan dan alun-alun

2. Toponim yang berkaitan dengan suatu jabatan atau nama pejabat, yaitu kauman, suronatan, domenggalan, tirtoyudo, sampangan, tanubayan, sorogenen, jagalaya dan Wonosaiam

3. Toponim yang berkaitan dengan suatu profesi dan etnis, yaitu pandean, tukangan, penjalan, gendingan, merbotan dan pecinan

4. Toponim yang berkaitan dengan aktivitas masyarakat, yaitu pasar, beguron dan krapyak

Ditemukannya toponim-toponim tersebut di atas tentunya melukiskan adanya kompleksitas struktur masyarakat kota Demak di masa lampau, masing-masing golongan menempati bagian-bagian kota sesuai dengan status, jabatan, profesi dan etnis. Di samping itu adanya pelapisan atau stratifikasi sosial juga tampak dalam kon- 
sep arsitektural atau pola pemukiman, yaitu lapisan atas akan dekat pemukimannya dengan kraton dan lapisan bawah mengitari di bagian luarnya. Namun sebenarnya untuk melihat kondisi struktur sosio-arsitektural kota Demak kuna tersebut telah sangat kabur. Hal ini disebabkan toponim-toponim tersebut juga telah banyak yang hilang dan mengalami pergeseran, di samping itu juga sedikitnya temuan data arkeologi, semuanya disebabkan oleh perkembangan kota Demak hingga sekarang.

Uka Tjandrasasmita(1985) menggolongkan kota-kota kerajaan dari jaman perkembangan islam di Indonesia ke dalam kota pra-industri. Istilah kota pra-industri ini diambil dari pendapat Gideon Sjoberg (1960) untuk menggolongkan kondisi masyarakat kota ke dalam kota pra-industri dan kota Industri Maju. la berpendapat bahwa kota pra-industri itu merupakan kota yang masih bersifat tradisional, namun mempunyai tiga prasyarat bagi terbentuknya kota pra-industri ini, yaiu (1) kondisi ekologi yang cocok, (2) teknologi yang cukup berkembang, dan (3) adanya organisasi sosial yang kompleks dengan struktur kekuasaan yang berkembang di atasnya.

Telah disebutkan terdahulu bahwa pusat kerajaan Demak diperkirakan terletak di daerah pantai yang subur karena diwarnai dengan adanya sungai (Tuntang) yang melintas di kawasan ini. Kondisi ini tentu merupakan suatu pertimbangan ekologis dari penguasa kerajaan Demak dalam memilih lokasi pusat kerajaan, walaupun kemudian dilegitimasi secara budaya misalnya dengan menyebut daerah ini dengan nama Glagahwangi. Keadaan seperti ini memungkinkan kawasan Demak ini tumbuh sebagai pusat pemukiman dan mendorong berkembangnya berbagai sistem tekonologi, karena berada di jalur perhubungan laut maupun daerah pedalaman. Berkembangnya sistem teknologi akan memerlukan adanya pembagian, pengaturan dan pengawasan kerja, dan akhirnya menyebabkan meningkatnya kegiatan ekonomi. Kompleksitas kegiatan ekonomi menyebabkan adanya penumpukan surplus yang muncul sebagai akibat dari meningkatnya arus barang dan jasa yang masuk di kota dari daerah (kota) lain serta dari daerah-daerah hinterland (penyangga). Dalam hal ini maka srtuktur kekuasaan (politik) akan berkembang pula untuk mengelola dan mengawasi kompleksitas kegiat-an sosial ekonomi dengan tujuan untuk menca-pai efektivitas dan efisiensi ekonomi. Karena itu di kota (pra-industri) terbentuk pembagian atau spesifikasi bidang pekerjaan meliputi bidang pengelolaan dan pengawasan, yang akhimya menyebabkan munculnya stratifikasi sosial sebagai manifestasi dari organisasi sosial yang kompleks di kota. Munculnya stratifikasi sosial ini memerlukan pengesahan dan pembatasan sosial melalui pranata-pranata sosial yang bersifat simbolik. ${ }^{5}$

Menurut Sjoberg (1960:108-110) gejala yang paling menonjol di dalam struktur sosial pada kota pra-industri adalah dikotomi antara la-pisan atas dan lapisan bawah dalam stratifikasi sosial. Perilaku sosial, cara bertindak, berbicara, berpakaian dan sebagainya, ditentukan sekali oieh keanggotaan individu di dalam status-status tertentu, serta diawasi oleh masyarakat itu sendiri. Anggota-anggota lapisan atas berpengaruh pada masyarakat kota dan desa-desa di sekitarnya (daerah hinterland) dan menempati kedudukan-kedudukan tinggi di dalam struktur hirarki yang timbul di dalam masyarakat, yaitu di dalam birokrasi pemerin-tahan, birokrasi militer dan birokrasi agama. Anggota-anggota lapisan bawah memegang fungsi rendahan dalam birokrasi-birokrasi itu, yaitu menjadi pedagang, petani, tukang, prajurit dan sebagainya.

Munculnya stratifikasi sosial tersebut kemudian juga berpengaruh pada pola pemukiman penduduk dan menyebabkan terjadinya stratifikasi penggunaan ruang di kota. Karena itu deferensiasi (struktur) keruangan di dalam kota praindustri baik secara vertikal maupun horisontal merupakan manifestasi dari deferen-siasi struktur masyarakatnya. Hal ini sering tercermin pada pembagian pemanfaatan ruang maupun bentukbentuk bangunan yang sesuai dengan pelapisan sosial yang terjadi dalam masyarakat. Sebagai suatu bentuk kota pra-industri, maka secara arsitektural kota-kota kuno di Jawa senantiasa juga diwarnai dengan kompleksitas struktur sosial yang heterogen-majemuk itu, melalui pembagian ruang atau pengelompokan pemukiman di kota atas dasar jabatan, status, profesi, pendapatan, ras bahasa dan sebagainya. Secara horisontal maupun vertikal, para pejabat (politik, ekonomi, agama, dsb.) atau golongan atas akan menempati posisi-posisi strategis dan akan melakukan aktivitas-sktivitas di bangunan-bangunan pemerintah atau pusat-pusat agama di pusat-pusat kota. Sedangkan golongan menengah dan ba-wah cenderung akan menempati bagian-bagian kota yang semakin ke pinggiran. Jenjang-jenjang sosio-arsitektural ini akan lebih jelas lagi terlihat pada kota-kota yang semakin besar atau penting kedudukannya, misalnya ibukota kerajaan. Nama-nama tempat (toponim) di dalam kota akan

5 Pranata-pranata sosial tersebut sebenarnya mengandung muatan simbol-simbol sosial untuk menjembatani dan membatasi hubungan atau interaks sosial sebagai akibat adanya stratifikasi atau pelapisan sosial dalam masyarakat 
menunjukkan segala bentuk dan jenis kegiatan masyarakat kota, meliputi pula jenjang-jenjang kedudukannya.

Munculnya pengelompokan ini biasanya didasarkan atas pertimbangan ekonomis dan politis, sebab sarana-prasarana perekonomian dan komunikasi di kota pra-industri biasanya masih sangat terbatas. Umumnya kegiatan produktif mereka masih berskala rumah tangga, karena itu untuk dapat memenuhi kebutuhan barang-barang di kota yang cukup besar itu mereka harus mengeiompok berdasarkan pekerjaan-pekerjaan tertentu untuk lebih memudahkan mereka saling berkomunikasi. Di samping itu pengelompokan ini juga akan memudahkan pengawasan dan koordinasi politis. Perluasan kegiatan politik dan penempatan elit-elit politik di daerah-daerah administratif di luar kota, dilengkapi pula dengan struktur politik yang stabil di kota dengan komunikasi dan pengawasan yang cukup berkembang, maka hal ini dapat mendorong terwujudnya kota sebagai suatu pusat kerajaan atau emperium yang besar seperti halnya kota pusat kerajaan Demak. Catatan sejarah juga telah membuktikan bahwa Demak merupakan sebuah ibukota kerajaan cukup besar pengaruhnya di Jawa dan beberapa kawasan Nusantara.

Runtuhnya kerajaan Demak, di samping disebabkan oleh masalah politis atau perebutan kekuasaan, tetapi kemunginan faktor ekologis juga berpengaruh. Derasnya proses sedimentasi di kawasan Demak yang menyebabkan pusat kerajaan Demak semakin jauh dari pantai, hal ini diperkirakan juga menyebabkan kota Demak semakin kurang strategis sebagai pusat kerajaan, dan akhirnya dipindahkan ke Pajang.

\section{Kesimpulan}

Catatan sejarah telah membuktikan demikian berperannya kerajaan Demak di masa lampau, terutama dalam proses penyebar luasan asgama Islam di Jawa dan beberapa kawasan $\mathrm{Nu}$ santara. Namun demikian mengenai letak, kon-disi sosial budaya dan kondisi lingkungan pusat kerajaan ini belum diketahui secara pasti. Oleh karena itu beberapa hal penting yang dapat dikemukakan sebagai kesimpulan dalam laporan penelitian ini adalah sebagai berikut

1. Dari sudut pandang geografis sekitar abad 15 masih terjadi genang laut yang mengakibat-kan terpisahnya pulau Jawa dengan kompleks gunung Muria. Derah-daerah Demak, Kudus, Pati, Welahan dan Kalinyamat pada sekitar abad 15-17 diperkirakan merupakan daerah tepi pantai/selat yang memisahkan antara kompleks gunung Muria dengan pulau Jawa. Dalam hal ini diperkirakan daerah Kudus, Pati,
Welahan dan Kalinyamat terletak di pantai kompleks Gunung Muria, sedangkan daerah Demak, Yuwana dan Rembang terletak di pantai Pulau Jawa. Proses pembentukan tombolo atau proses sedimentasi terjadi dengan cepatnya secara terus menerus di daerah (selat) ini berupa material-material yang berasal dari Zona Kendeng, Zona Rembang, Zona Randublatung, kompleks Muria dan Papara Laut Jawa, hal ini telah menyebabkan selat in cepat mengalami pendangkalan dan berubah menjadi daratan. Kini daerah-daerah tersebut berada pada Depresi Semarang-Rembang

2. Karena Demak terletak pada daerah ini maka di masa lampau merupakan daerah pantai yang subur, dan keberadaan sungai Tuntang (lama) yang melintasinya dapat dimanfaatkan sebagai sarana transportasi, pertanian, peda-gangan, politik dan penyiaran agama, sehing-ga dipilih sebagai daerah pusat pemerintahan kerajaan Tepatnya lokasi pusat kerajaan itu dipilih pada daerah aliran sungai yang alurnya melengkung seperti terlinat pada denah kota Demak Tempat ini memang tampak strategis, karena itu pula dari pertimbangan ekologis diperkirakan kraton Demak menghadap ke arah utara. Hal ini tampaknya juga tidak bertentangan dengan tradisi budaya bahwa kraton di Jawa umumnya menghadap ke arah utara atau paling tidak ke arah laut, karena diperkirakan di masa lampau di sebelah utara Demak terdapat selat.

3. Berdasarkan catatan perjalanan Portugis dan Belanda serta berdasarkan kitab-kitab Babad dapat diketahui bahwa pada sekitar abad ke 16 telah berdiri kerajaan Demak. Dari sumbersumber tersebut dapat diketahui bahwa pusat kerajaan Demak itu dilalui sungai (Tuntang) yang dapat dilayari oleh kapal-kapal dagang. walaupun kalau masuk harus menunggu air laut pasang. Di samping itu beberapa kitab babad melukiskan bahwa kraton Demak itu cukup megah seperti halnya kraton Majapahit yang menghadap ke arah utara. Di samping itu ditunjukkan bahwa di lingkungan kraton terdapat unsur-unsur (bangunan) seperti setinggil. alun-alun dan masjid yang letaknya tidak saling berjauhan. Masjid Agung Demak sendiri banyak dikisahkan oleh kitab-kitab Babad sebagai masjid para Wali, yang dibumbui de-ngan cerita-cerita yang bersifat legendaris

4. Kondisi ekologis seperti tersebut di atas memungkinkan Demak tumbuh menjadi suatu kota pra-industri atau menjadi ibukota kerajaan. Munculnya pusat-pusat pemukiman ini menandai adanya ekologi yang cocok, yang akhirnya mendorong berkembangnya tekno- 
logi dari berbagai bidang, termasuk teknologi transportasi dan munculnya pelabuhan. Kemajuan teknologi akhirnya mendorong terbentuknya kompleksitas aktivitas sosial dan munculnya struktur kekuasaan yang semakin berkembang mengarah kepada terbentuknya sua. tu emperium yang besar.

5. Terbentuknya kompleksitas sosial tersebut menandai suatu bentuk adaptasi sosial dan budaya masyarakat kota Demak dalam berbagai strategi kehidupan. Artinya adaptasi di kota secara eksternal terjadi atas surplus dari daerah penyangga (hintertand) atau wilayah pengaruh dari para penguasa di kota. Secara internal proses adaptasi kota ini merupakan manifestasi dari kompleksitas kegiatan masyarakat terbentuknya stratifikasi sosial dan stratifikasi penggunaan ruang di kota. Karenanya terbentuklah pola pemukiman masyarakat kota pra-industri atas dasar status sosial, meliputi jabatan, golongan, profesi, agama, dan etnis. Nama-nama tempat (toponim) yang ditemukan di kota Demak menandai bentuk-bentuk stratifikasi sosial dan keruangan tersebut.

6. Adanya Masjid Agung di pusat kota Demak menandai lekatnya kehidupan sosial masyarakat dalam kehidupan religius sebagai tem-pat berlindung. Di samping itu ciri kota pra-in-dustri menunjukkan lekatnya kehidupan poli-tik, ekonomi dan agama, yang dimanifestasi-kan dalam bentuk satu kesatuan pengawasan, seperti adanya kraton, alun-alun, masjid dan pasar yang letaknya berdekatan di pusat kota. Pusat kota/kerajaan ini dikitari oleh pemukiman penduduk kota yang kini masih dapat ditemukan dalam bentuk toponim-toponim walaupun harus dilihat secara hati-hati.

7. Sebagai kesimpulan akhir dapat dijelaskan perkembangan kota Demak sebagai pusat kerajaan dilandasi kondisi ekologi yang cocok. Kondisi ekologi ini mendorong berkembangnya sistem teknologi, dan munculnya kompleksitas sosial dan struktur kekuasaan di ko-ta Demak, walaupun dalam hubungan saling mempengaruhi. Kemudian kota Demak diperkirakan tumbuh menjadi pusat emperium yang cukup besar, walaupun akhirnya perubahanperubahan kondisi ekologis dan kondisi sosial politik menyebabkan runtuhnya kerajaan.

\section{KEPUSTAKAAN}

Ambary,Hasan M,dkk.tt. Laporan Hasil Survai Kepurbakalaan di Daerah Demak (Jawa Tengah) No 1B Jakarta:Pusat Penelitian Purbakala\&Peninggalan Nasional Dep.P\& K
1977. Laporan Ekskavasi Tridonorejo Demak No. 7, Jakarta:Pusat Penelitian Purbakala \& Peninggalan Nasional Dep.P\& $K$

Anom,I Gusti Ngurah,dkk(ed).1985-1986. Laporan Pemugaran Masjid Agung Demak, Jakarta-Yogyakarta:Proyek Pemugaran dan Pemeliharaan Masjid Agung Demak Bantuan Presiden

Anonim (Alih aksara dan Bahasa).1985. Serat Babad Tembayat Jakarta:Depdikbud Proyek Penerbitan Sastra Indonesia dan Daerah

Bemmelen Van, RW.1949. The Geology of Indonesia Vol. IA, Martinus Nijhoff, The Hague, Netherland.

Brumund, J.F.G. 1980. Bijdragen tot de Kennis van Het Hindoeisme op Java. VBG XXXIII Batavia

Cortesao,Armando(ed.).1944. The Suma Oriental of Tome Pires and the Book of Fransisco Rodrigues. The Hakluyt Society.

Graaf,H.J.de\&Pigeaud,Th.G. Th, 1985. KerajaanKerajaan Islam di Jawa Peralihan dari Majapahit ke Mataram. Jakarta: PT Grafiti Pers

Olthof, W.L.. 1941. Poeniko Serat Babad Tanah Djawi Saking Nabi Adam Doemoegi ing Tahoen 1647 dalam Meinsma, Babad Tanah Jawi (prosa), S'Gravenhage: W Van Hoeve Martinus Nijhoff.

Ongkosongo, O.S.R. 1981. Tombolo dan Bekas Pulau Kuarter di Pulau Jawa Dan Bali, Proseding Pertemuan IImiah ahli Geologi Indonesia ke 10 di Bandung, Publikasi oleh Ikatan Ahli Geologi Indonesia, Bandung

Panitia Penyusun Hari Jadi Kabupaten Demak. 1991.Sejarah dan Harijadi Kabupaten Demak, Demak:Pemda Tk.II Kab. Demak.

Prawirayuda, Pandji. 1988. Babad Majapahit dan Para Wali Jilid 3 Jakarta:Proyek Penerbitan Buku Sastra Indonesia \& Daerah Depdikbud

Sastronaryatmo, Mulyono (alih bahasa). 1981. Babad Jaka Tingkir (Babad Pajang). Jakarta Proyek Penerbitan Buku Sastra Indonesia dan Daerah Depdikbud. 
Sjoberg,Gideon.1960. The Preindustrial City: Past and Present New York London:The Free Press

Subalidinata \& Supriyanto(ahli aksara \& bahasa). 1988.Serat Kandhaning Ringgit Purwa, jilid 2, Jakarta: Jambatan dan KITLV.

Tjandrasasmita,Uka.1985. Kota Pernukiman Masa Pertumbuhan Kerajaan-kerajaan Pengaruh Islam di indonesia (Penerapan Arkeologi dan Konsep IImu-ilmu Sosial), Proceeding PIA III, Jakarta:Puslit Arkenas.
(ed).1984.Sejarah Nasional Indonesia III, Jakarta: Balai Pustaka.

Valentijn,Francois. 1862. Oud en Nieuw Oost Indiën Derde Deel Tweede Uitgave Amsterdam:Wed. J.C. Van Kesteren \& Zoon. 


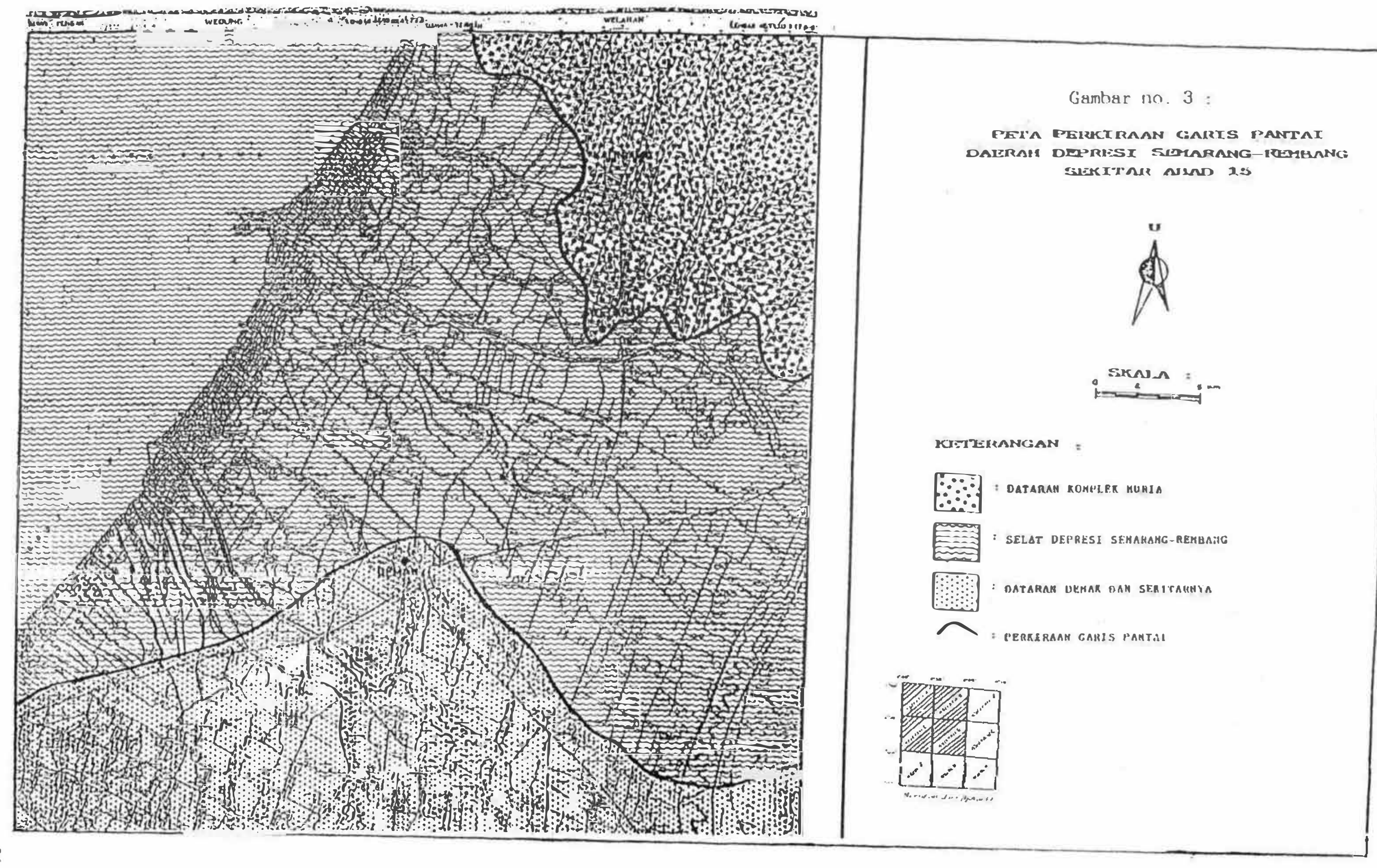




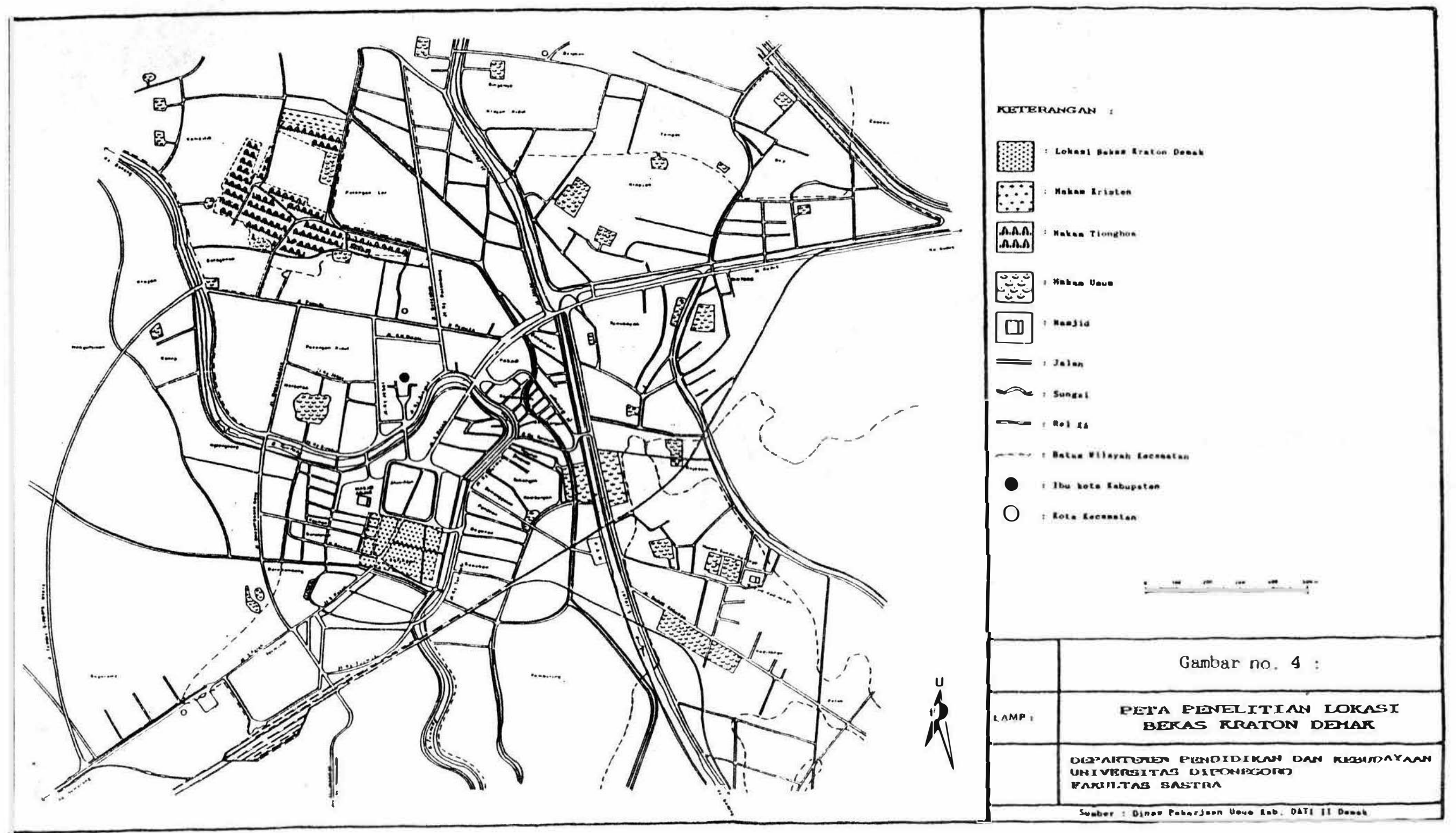




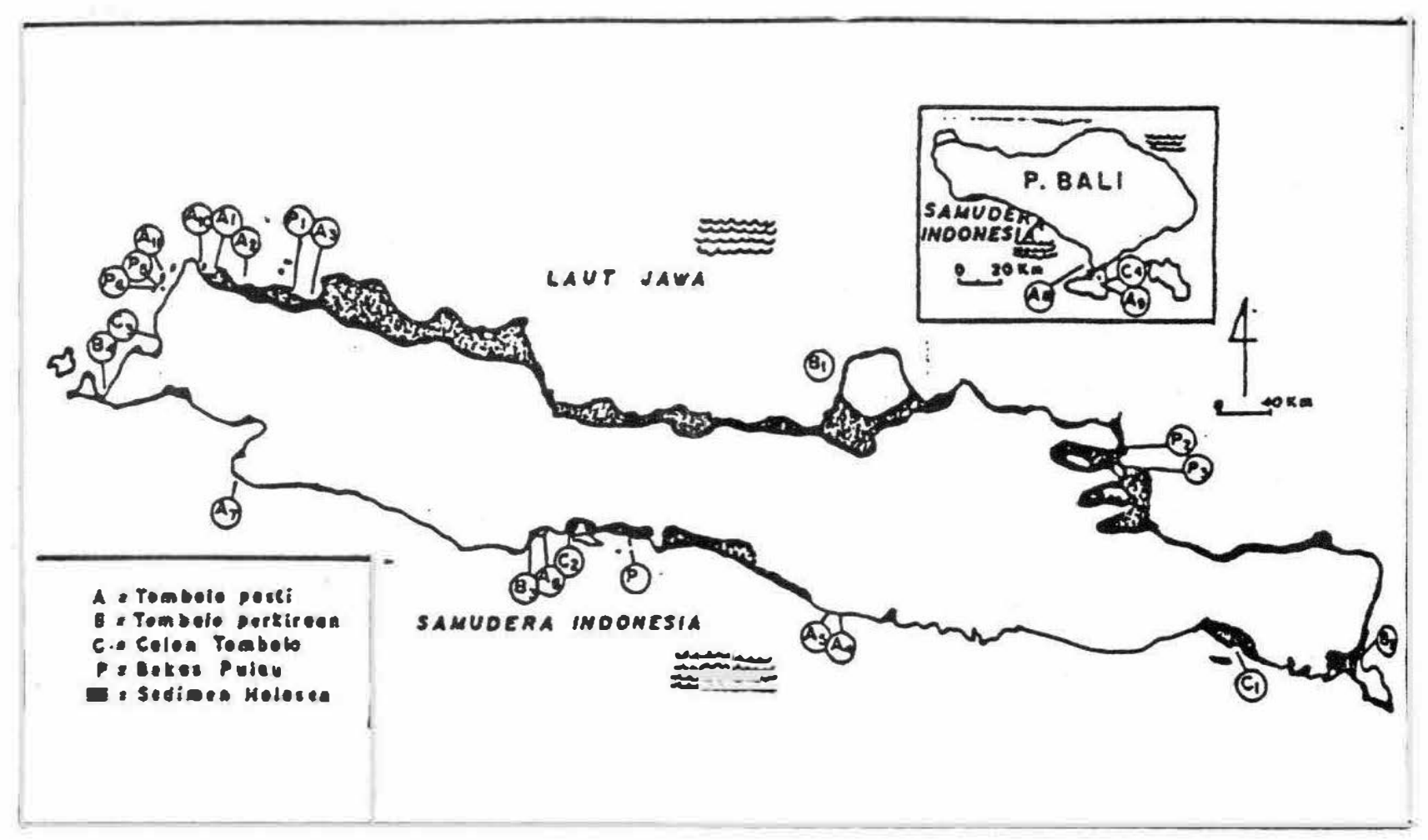

Gambar no. 1 : Peta Sebaran Sedimen Holosen dan Pembentukan Tombolo di Jawa dan Bali (Ongkosongo, 1981). 


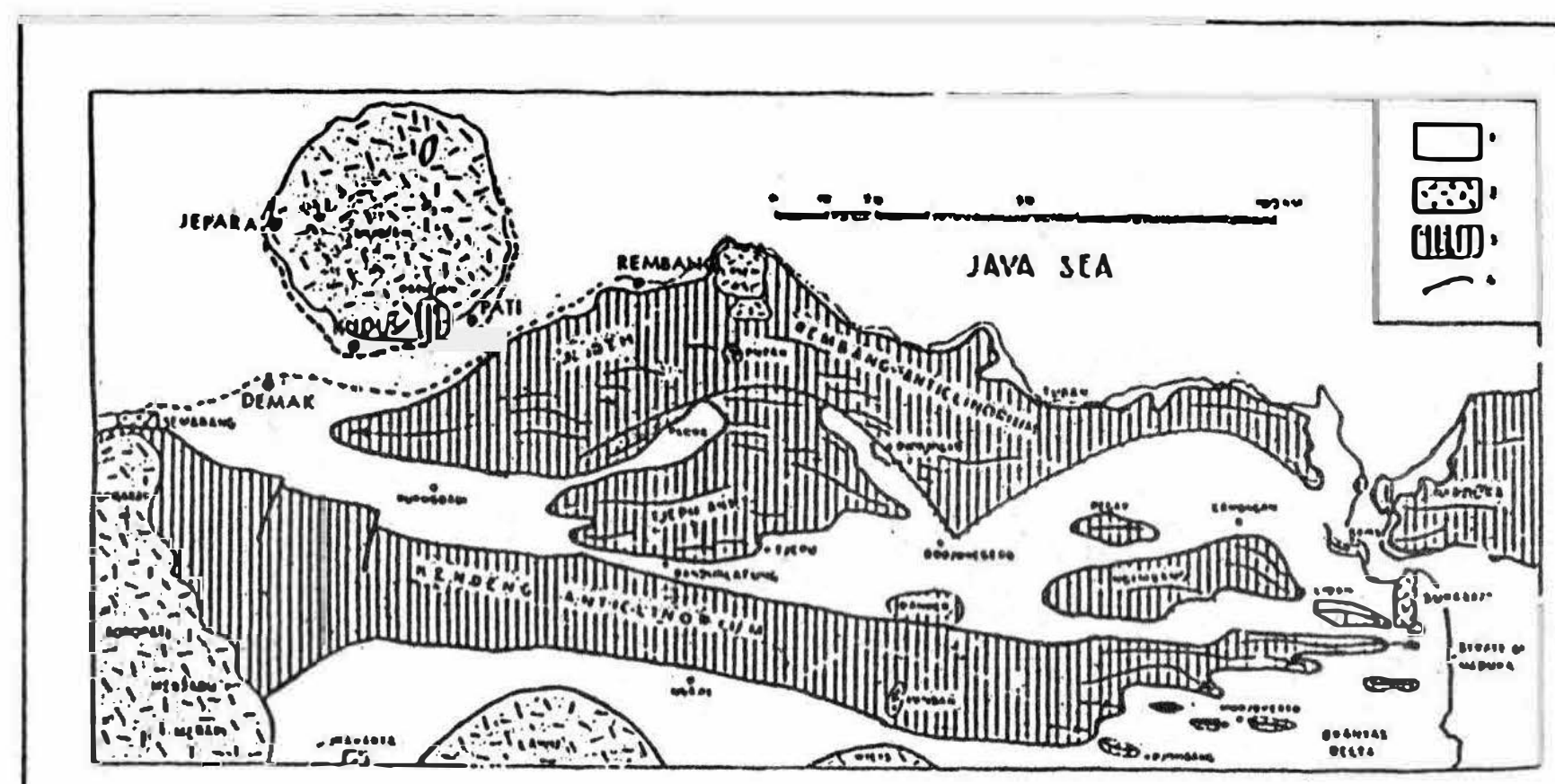

Reterangan :

1. Aluvial. 2. Volkanik kuarter.

3. Batuan Heogen. 4. patahan.

.. Perkiraan bentuk garis pantai sckitar abad $15-18$

Gambar no. 2 : Perkiraan keadaan Depresi Semarang-Rembang sekitar abad 15 .. 18. Modifikasi dari peta Pisiografi Jawa Timur Utara (BEMMELEH, 1949). 